abundant. Macrobenthic species were absent from the profundal zone of the Lake, which showed all the important characteristics of a polluted water-body.

\section{REFERENCES}

AMERICAN PUBLIC HEALTH ASSOCIATION [cited as APHA] (1955). Standard Methods for the Examination of Water, Sewage and Industrial Wastes, 10th edn. APHA, New York, NY, USA: $x x+522$ pp., illustr.

FORSYTH, D. J. (1976). Insects and aquatic ecosystems. New Zealand Entomologist, 6(2), pp. 132-3.

INDIAN COUNCIL OF MEDICAL RESEARCH [cited as ICMR] (1963). Manual and Methods for the Examination of Water, Sewage and Industrial Waste. Special Report, Series No. 47, New Delhi, India: $v+180$ pp.

NDUKU, W. K. (1976). The distribution of phosphorus, nitrogen and organic carbon in the sediments of Lake Mcllwaine, Rhodesia. Trans. Rhod. Scient. Ass., 57(6), pp. 45-60.

PANDE, J. \& DAS, S. M. (1980). Metallic contents in water and sediments of Lake Naini Tal, India. Water, Air and Soil Pollution, 13, pp. 3-7.

PANT, M. C. \& SHARMA, P. C. (1978). Observations on some possible causal factors for winter fish mortality in Naini Tal Lake. Pp. 248-54, in Proceedings of the National Seminar on Resources, Development and Environment in the Himalayan Region. Department of Science and Technology, Government of India, New Delhi, India: xxxiii + 537 pp., illustr.

PANT, M. C., SHARMA, A. P. \& SHARMA, P. C. (1980). Evidence for the increased eutrophication of Lake Naini Tal as a result of human interference. Environ. Pollut. (Ser. B), 1, pp. 149-61.

ROSENBERG, R. (1977). Benthic macrofaunal dynamics, production and dispersion in an oxygen-deficient estuary of West Sweden. J. Exp. Mar. Biol. Ecol., 26, pp. 107-33.

SAWYER, C. N. (1947). Fertilization of lakes by agricultural and urban drainage. J. New England Water Work Associa. tion, 60, pp. 109-27.

THRESH, J. C., BEALE, J. E. \& SUCKLING, E. V. (1958). Examination of Waters and Water Supplies, 7th edn. E. Windle Taylor, London, England, UK: vi +841 pp., illustr.

VOLLENWEIDER, R. A. (1968). Scientific Fundamentals of the Eutrophication of Lakes and Flowing Waters with Particular Reference to Nitrogen and Phosphorus as Factors in Eutrophication. Report, O.E.C.D. Directorate of Scientific Affairs, Paris, France: 220 pp.

WELCH, P. S. (1948). Limnological Methods. McGraw-Hill, New York, NY: xviii + 381 pp., illustr.

WORLD HEALTH ORGANIZATION [cited as WHO] (1971). International Standards for Drinking Water, 3rd edn. WHO, Geneva, Switzerland: vi $+280 \mathrm{pp}$., illustr.

WRIGHT, S. (1955). Limnological Survey of Western Lake Erie. U.S. Fish Wildl. Serv. Spec. Sci. Rep. Fish., No. 139, $341 \mathrm{pp}$.

\title{
Starving Greylag Geese Saved in Spain
}

Quick action by the Spanish Government and the World Wildlife Fund early this year probably saved many thousands of migrating Greylag Geese (Anser anser) from starvation. An emergency feeding programme provided 100 metric tons of grain to feed up to 50,000 Greylag Geese which annually winter at the Doñana National Park in Spain before flying north to breed in northern Europe. The birds that winter in Doñana represent a major part of the Scandinavian breeding population of the species.

The Coto Doñana National Park was suffering from one of the worst droughts in years, and many animals were undergoing great difficulties in finding food and water for survival in January and early February, according to Catalina Brennan, Secretary-General of WWF Spain. The Spanish Minister of Agriculture, Jaime Lamo de Espinosa, took immediate action to a 4 February petition from WWF Spain, and instructed that 100 tons of grain be sent to the Park that very day.

In a prior action, Dr Jose Antonio Valverde, honorary director of the Doñana Biological Station, obtained 6 tons of rice to avoid catastrophe. After an exchange of telexes, the 4 national organizations in Scandinavia (Denmark, Norway, Finland, and Sweden) immediately agreed to pay for the emergency rice. A decade ago WWF Norway and WWF Sweden contributed more than US $\$ 100,000$ each to purchase land for the Doñana Biological Station.

Paul S. Wachtel, Public Affairs Coordinator
WWF International
Avenue du Mont-Blanc
1196 Gland
Switzerland

\section{Save Our Biosphere}

For the celebration of World Environment Day 1981, the Indian Society of Naturalists (INSONA) has brought out stickers entitled SAVE BIOSPHERE (Fig. 1). This is with a view to lending support to, and promoting in every possible way, The World Decade of The Biosphere, 1982-92 (starting ten years after 'Stockholm'), as proposed originally by Drs John R. Vallentyne, of the Canada Centre for Inland Waters, Ontario, Canada, J. R. Strickler, of the Australian Institute of Marine Science, Queensland, Australia, and Nicholas Polunin, of Environmental Conservation, Geneva, Switzerland.
The members of INSONA wish to identify themselves and their organization with the World Decade of the Biosphere, and hereby announce that they intend, through their programmes in the coming years, to promote and foster it in every possible way-with the objective of making everyone aware of The Biosphere, what it is, and how utterly we and all mankind depend upon it.

The facts and leadership statements on the subject which have appeared in recent issues of Environmental Conservation - the scientific journal devoted to global 